\title{
Aboriginal camps as urban foundations? Evidence from southern Queensland
}

\author{
Ray Kerkhove
}

\section{Musgrave Park: Aboriginal Brisbane's political heartland}

In 1982, Musgrave Park in South Brisbane took centre stage in Queensland's 'State of Emergency' protests. Bob Weatherall, President of FAIRA (Foundation for Aboriginal and Islanders Research Action), together with Neville Bonner Australia's first Aboriginal Senator - proclaimed it 'Aboriginal land'.

Musgrave Park could hardly be more central to the issue of land rights. It lies in inner Brisbane - just across the river from the government agencies that were at the time trying to quash Aboriginal appeals for landownership, yet within the state's cultural hub, the South Bank Precinct. It was a very contentious green space.

Written and oral sources concur that the park had been an Aboriginal networking venue since the 1940s. ${ }^{1}$ OPAL (One People of Australia League) House Queensland's first Aboriginal-focused organisation - was established close to the park in 1961 specifically to service the large number of Aboriginal people already using it. Soon after, many key Brisbane Aboriginal services sprang up around the park's peripheries. By 1971, the Black Panther party emerged with a dramatic march into central Brisbane. ${ }^{2}$ More recently, Musgrave Park served as Queensland's 'tent 
embassy' and tent city for a series of protests (1988, 2012 and 2014). ${ }^{3}$ It attracts 20,000 people to its annual NAIDOC (National Aboriginal and Islander Day Observance Committee) Week, Australia's largest-attended NAIDOC venue. ${ }^{4}$

This history makes Musgrave Park the unofficial political capital of Aboriginal Brisbane. While that legacy affected Weatherall's and Bonner's choice of this site for their 1982 proclamation, many Brisbane Aboriginal people already viewed Musgrave Park as their 'campsite' and 'home'.5

In 1985, Bob Weatherall asked me to evaluate the oral tradition that the park has always been an important meeting and camping place against the testimony of written history. ${ }^{6}$ The research highlighted written records from the 1890 s onwards, recalling a set of subcamps on the ridges of what is now the Brisbane High School end of Musgrave Park, continuing for 400 metres towards today's Dorchester Street and Somerville House (see Figure 1). Early residents Chas Melton and William Clark document 'hundreds' of Aboriginal people living on the ridges here during the 1840 s and 1850s, ${ }^{7}$ walking daily into South Brisbane town to sell, trade, work or beg. ${ }^{8}$ They recall 'bark and bough gunyahs under the trees at the foot of Highgate Hill, and on the slanting sides of Cumbooquepa (Somerville House)'.?

The report found that Musgrave Park had been a public reserve since the commencement of European settlement. Brisbane surveyors habitually allotted areas for water or recreational use in their mapping during the 1840s. Surveyor Henry Wade's 1844 map shows he left the area we now call Musgrave Park unassigned, presumably on account of its waterholes or Aboriginal occupants, as early accounts recall South Brisbane (then just a few houses) relied on a waterhole and swamp within this area. ${ }^{10}$ Aboriginal people were recorded camping around the ridges of this and the adjacent waterholes of Woolloongabba. In fact, the water was regularly carted from these waterholes to the emerging town by local Aboriginal children. ${ }^{11}$ By 1850, the area was officially called 'South Brisbane Reserve for Public Recreation and Extension'. ${ }^{12}$

\footnotetext{
3 'Musgrave Park, South Brisbane: Conservation Management Study' 2001: 9; The Conversation, 17 May 2012; Stringer, 19 October 2014.

4 See Romano 2008: 45.

5 Romano 2008: 48.

6 Kerkove 1985.

7 Brisbane Courier, 10 July 1915.

8 'The Passing of a Pioneer Explorer', Brisbane Courier, 15 March 1912: 12; Melton 1915 [1924].

9 Brisbane Courier, 10 July 1915.

10 Brisbane Courier, 15 March 1912: 12; Queenslander, 7 August 1909.

11 Kidd 2000: 14.

12 QSA AIA Series c. 1850.
} 


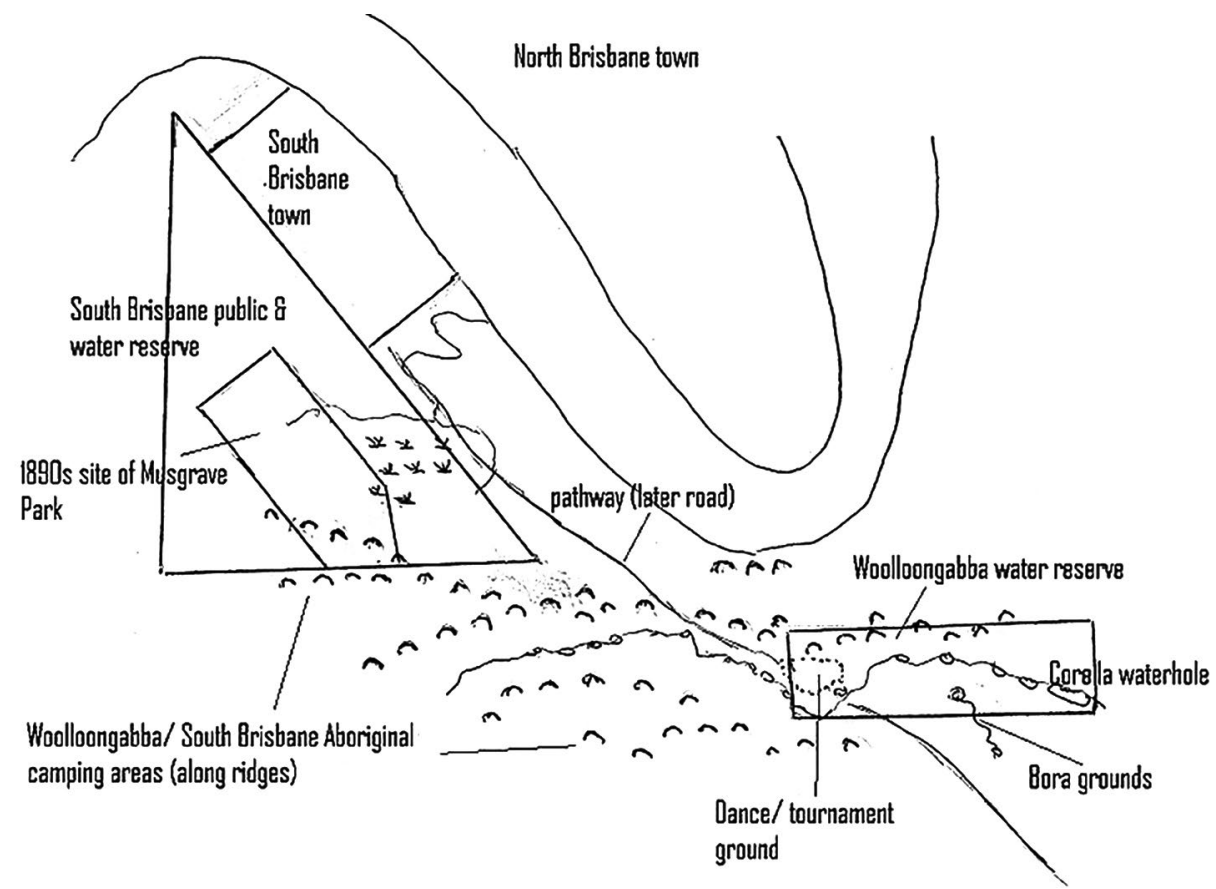

Figure 1: The relationship between the evolving South Brisbane/Musgrave Park and Woolloongabba Water/Recreation Reserves and Aboriginal camps.

Source: Author.

Between the 1880s and 1930s, South Brisbane Reserve shrank as housing encroached and the water supply was used up. The remaining core was renamed Musgrave Park in 1884 in honour the visit of Lord Musgrave. ${ }^{13}$ Thus, Musgrave Park was effectively a 'relic' of an Aboriginal camp and waterhole.

It was a relic that has refused to go away. In 1900, Aboriginal men were still collecting bunya nuts at Mater Hill near the park. ${ }^{14}$ Perhaps because the park lay halfway between the home of the Queensland Aboriginal Protector (Archibald Meston) and the West End Aboriginal Girl's Home, Aboriginal men continued to 'loiter' here. A few decades later, this 'loitering' had turned the park into Brisbane's main venue for Aboriginal people to meet and socialise.

13 Kerkhove 1985.

14 Sunday Mail, 16 June 1935. 


\section{Musgrave Park as a pre-settlement campsite}

Musgrave Park's Aboriginal use long pre-dates the 1940s. Does this equate to the area 'always' being a meeting and camping ground? Until the1850s, it retained its swamp, woodland and rainforest resources. Aboriginal people supplied thatching to South Brisbane from the reeds of this swamp. Traditionally, this was Kurilpa ('place of bush rats'), a rainforest and wetlands pocket covering today's West End and South Brisbane. It was favoured for Aboriginal hunting drives on bush rats, scrub turkeys and other foods. ${ }^{15}$

Within Kurilpa, Michael Strong's archaeological survey concluded that Musgrave Park offered the best site for a base camp:

the mosaic of vegetation patterns ... would have provided a rich variety of food, both vegetable and animal, and many other resources such as medicines and bark for construction of housing. The environmental context would have ... provided for the larger gatherings ... It is possible that ... a camp site existed in the Musgrave Park area, as it offered a ridge sitting above significant wetlands and a creek ... The area also offered a range of nature resources that would have provided most, if not all, requirements of daily life. ${ }^{16}$

Strong also noted a pathway threaded from Musgrave Park to a known river crossing (Kurilpa Point) - again suggesting that it was the location of a camp. ${ }^{17}$ Stone axes and scrapers have been found within and very close to the current park. ${ }^{18}$ This again implies the camp pre-dates settlement.

Between 1827 and 1830, there was no European settlement on this side of the river, yet Aboriginal people are recorded conducting disastrous and continuous raids on the area's maize crops. We know they did this from a camp close by, as Commander Logan sent soldiers to storm the camp to dissuade further raids. ${ }^{19}$

\section{Rethinking the nature of Aboriginal campsites}

A hundred years ago, acknowledging the persistence of a camp beside Brisbane City was not deemed important. Aboriginal people, being classed 'closer to apes than angels' ${ }^{20}$ were assumed to be 'just passing through' like migratory birds. As Buchan

15 Brisbane Courier, 22 March 1930; Queenslander, 16 September 1916.

16 Strong and Archaeo 2003: 32, 34.

17 Strong and Archaeo 2003: 32, 34.

18 Kidd 2000: 6.

19 Australian, 25 July 1827; Petrie 1904: 209.

20 Cowlishaw 1988: 63. 
noted, Australia's European founders clung to Enlightenment views that huntergatherers had 'an absence of architectural culture ... no thought for the morrow'. ${ }^{21}$ This helped justify colonial claims over Indigenous lands. ${ }^{22}$

However, since the 1970s, Aboriginal living areas have been reconsidered through archaeological work on 'permanent villages' in western Victoria. ${ }^{23}$ Julia Coleman and Jay Hall identified Aboriginal 'villages' in south-eastern Queensland and northeastern New South Wales. ${ }^{24}$

It was already known that base camps occupied well-defined, fairly permanent areas. ${ }^{25}$ Hall, Lilly and Ulm showed that larger camping grounds had archaeological signatures ${ }^{26}$ with well-planned layout and placement, ${ }^{27}$ and nearby 'amenities' such as ceremonial grounds, burial grounds, a public space and a refuse tip..$^{28}$ This matched the observations of early explorers of the area - for example, Leichhardt in his travels between NSW and Wide Bay (Queensland):

over their territory ... they have regular 'camps' like the villages and inns of the whites found in other countries. They know the localities (of these) extraordinarily exactly. ... These 'camps' are only little distant from one another and they journey only a short stretch during a day. ${ }^{29}$

Colin Munro - an early Fernvale pioneer - describes a typical southern Queensland camp as having 50 huts of five to six persons each. ${ }^{30}$ This gives a total of 250-300 persons per camp. Another early south-eastern Queensland settler, Thomas Petrie, states: 'the Turrubul (Brisbane) tribe certainly did not all congregate together in one spot but camped in lots of about 200 each, and they visit each other. ${ }^{31}$ These populations included non-locals. Early settler Thomas Petrie grew up speaking the local languages. He describes Brisbane's traditional camps hosting visitors from many other areas - the Logan, Stradbroke Island, Bribie Island, Ipswich and Wide Bay. ${ }^{32}$ Regular sub-camps were allotted to the visitors. Lengthy gatherings were held, for hunts, ceremonies and tournaments, and for marriages. ${ }^{33}$

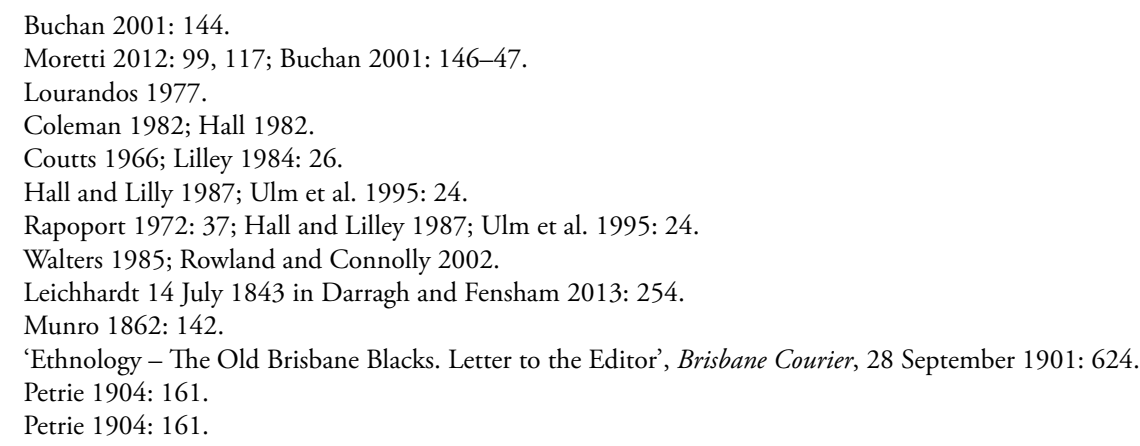




\section{Negative images of historic Aboriginal camps}

If camps sometimes held large numbers of residents, they must have been highly visible in the colonial landscape, and would have been initially larger than European settlements. Where they continued into recent times, they may be assumed to have had an impact on the design of the towns that enveloped them.

Paul Memmott has shown that Aboriginal camps were a ubiquitous feature of Australian towns. ${ }^{34}$ This means that every Australian town had an Indigenous spatial component. Such residential presence is rarely mentioned in colonial histories, largely because it was sidelined or not 'noticed'. ${ }^{35}$ Nineteenth-century paintings show Aboriginal people on 'the edges and fringes of urban settlement', even when their urban presence is clearly recorded. ${ }^{36}$

This bias also pervades perceptions of Indigenous urban heritage. Suburban and town museum displays concentrate on 'Dreaming stories' or other intangibles. ${ }^{37}$ Studies of Aboriginal societies overwhelmingly emphasise remote rather than urban communities. ${ }^{38}$ If Aboriginal heritage is honoured within urban settings at all, it is through plants, animals or artefacts from before settlement, as though Indigenous society of the last two centuries is irrelevant. ${ }^{39}$

Ironically, the efforts of Charles Rowley, Henry Reynolds and other historians in highlighting the brutality of colonisation created a narrative wherein Aboriginal camps were assumed to vanish with the tide of invasion. In this scenario, Aboriginal society was so disrupted by the invaders that traditional life patterns immediately dissolved and traditional living spaces were replaced by 'fringe camps'. Fringe camps were not viewed as traditional living spaces, ${ }^{40}$ but rather as something the white community created from detribalised 'refugees', who gravitated to the towns and were assigned 'leftover' lands. ${ }^{41}$ In other words, 'fringe camps' are viewed as subsidiary, artificial living areas. Rod Fisher painted Brisbane 'fringe' camps as 'underdeveloped'. ${ }^{42}$ Ross Johnston viewed them as undergoing 'increasing degradation'. ${ }^{43}$ Other historians described camp residents as 'slaves' providing cheap sex and labour, ${ }^{44}$ and the inhabitants spiralling into crime, addiction and suicide. ${ }^{45}$

34 Memmott 1996; Greenop and Memmott 2006: 167.

35 Byrne 2003: 73, 82.

36 Russell 2015: 28.

37 Goodall 1999: 167, 169.

38 Anderson and Jacobs 1977: $12 \mathrm{f}$.

39 Hinkson 2002: 62, 69.

40 Morgan 2006.

41 Reynolds 1978; Coleman 1979; Hunter 1991; Reynolds 1990.

42 Fisher 1992.

43 Johnston 1988: 56-57.

44 Coleman 1979: 38; Evans 1984; Reynolds 2013: 118.

45 Evans et al. 1975; Evans 1999; Fisher 1992: 73. 


\section{Inaccuracies in the 'fringe camp' image}

It cannot be denied that substance abuse, mass removals or massacres occurred at historic camps, as did exclusion from certain metropolitan areas. ${ }^{46}$ Land acquisition and associated loss of natural resources degraded and confined Aboriginal living areas. This affected how Aboriginal people valued their camping grounds. For example, Francesca Merlan's research near Katherine, Northern Territory, found Aboriginal residents believed 'rainbols' (spirits) had been 'thrown away' by construction work ${ }^{47}$ - inducing them to hold their living areas in similar disrespect. ${ }^{48}$ However, change was not always or entirely negative. The influx of Western goods and ideas provided a volatile space for growth and innovation. ${ }^{49}$ Hinkson and Smith argue that the resultant 'hybridity' did not create a people 'caught between two worlds' but rather a more contemporary manifestation of Aboriginal culture. ${ }^{50}$ Certainly, long-term Aboriginal values continue in urban communities of Brisbane, and the layout of modern 'town camps' manifest traditional Indigenous forms, updated with new technologies. ${ }^{51}$ More importantly, as Paul Irish and Michael Ingrey have found in east Sydney, camps and Aboriginal housing continue to occupy the same precolonial spaces:

Even today, these camps are often thought of as fringe camps, as if Aboriginal people had no choice over location and were left trapped and dependent on the outer edge of European settlements. The continued occupation of rich resource areas and the likely maintenance of cultural obligations to country show that this was not the case. ${ }^{52}$

Indeed, there is increasing archaeological evidence that 'fringe' camps in many cases perpetuated camps that existed before settlement. Archaeologist Peter Kabaila found that the Yass region's Aboriginal reserve was established during the nineteenth century 'because it was near an existing camp by the river'. ${ }^{53}$ There are further examples of this from the mid-north coast of New South Wales, ${ }^{54}$ Brisbane Airport ${ }^{55}$ and south Kimberley. ${ }^{56}$ Patricia Bourke located many historic camps 'on top of older pre-contact sites' within Darwin. ${ }^{57}$

\footnotetext{
46 Robinson 2002; Greenop and Memmott 2006: 259.

47 Merlan 1998: 51-53.

48 Merlan 2006: 179f.

49 Merlan 2005: 169.

50 Hinkson and Smith 2005: 161-62.

51 Greenop 2008; Memmott 2002: 66f; Memmott 2007: 110, 232, $258 f$.

52 Irish and Ingrey 2013: 84-85. See also Irish 2017; 'A History of Aboriginal Sydney', www.historyofaboriginal sydney.edu.au.

53 Kabaila 2012: 16.

54 Smith and Beck 2003: 66f.

55 Hall and Lilley 1987.

56 Smith 2001: 23.

57 Bourke 2005: 54.
} 
Early government reports support this evidence of continuous occupation. The Annual Report on the State of Aboriginals in New South Wales (1852) observed Aboriginal groups quitting traditional campsites during frontier violence, only to move back when peace was restored, with residents becoming workers on New South Wales homesteads. ${ }^{58}$ This pattern was replicated on the Darling Downs in Queensland. ${ }^{59}$

\section{Historic camps as vibrant colonial communities}

Despite being physically different from European towns, Aboriginal 'town camps' were places of enculturation, socialisation and identity, as European villages were. ${ }^{60}$ $Y u m b a$ - a Queensland word for fringe camp - means 'home'. ${ }^{61}$ In other words, these places were not 'leftover lands' but cherished sites. Herb Wharton's account of Cunnamulla yumba describes a warm, supportive community, rich in sociocultural life. ${ }^{62}$ In the 1980s, the Mitchell Aboriginal community collected elders' memories of Mitchell yumba. Their account shows their yumba played a key role in maintaining local sites, bush tucker, kinship and crafts. ${ }^{63}$

The occupants of 'town camps' were also the lifeblood of rural industries. ${ }^{64}$ Their contribution to the pastoral industry has been explored, ${ }^{65}$ but they were also essential to fishing, oystering, timber-getting and domestic services. Mitchell yumba provided many of the town's farm and stockhands, domestic servants, fencers, ringbarkers, hunters of 'vermin', fishers and bullock-drivers. ${ }^{66}$

As sole traders or working for white bosses, camp residents were major suppliers of 'bush produce': fish, crabs, oysters, honey, baskets, native fruits and nuts, pelts, ornamental flowers and plants, bark and even fur cloaks. ${ }^{67}$ In 1847, the potential of Moreton Bay prawns was discovered from Aboriginal fishers:

During the last week, the natives have procured immense quantities of this delicious crustaceous fish ... They are much larger than the same kind of fish caught on the southern coasts ... and would no doubt turn out a profitable export ... Several of the Inhabitants have potted, salted and pickled them, in large quantities, for the purpose of forwarding them to Sydney. ${ }^{68}$

58 NSW Archives, 'Annual reports on state of the Aborigines', 22 September 1852.

59 Feehely 1997.

60 Henry 1999.

61 Godwin and L'Oste-Brown 2002: 198.

62 Wharton 1999: 3-5.

63 Mitchell Aboriginal Community 1985: $24 \mathrm{f}$.

64 Memmott 1996; Greenop and Memmott 2006.

65 Reece 1974; Reynolds 1974; Loos 1982: 28; Pope 1988.

66 Mitchell Aboriginal Community 1985: 17, 32-33.

67 Kerkhove 2013.

68 Moreton Bay Courier, 16 October 1847: 3. 
Knowledge of geography, geology, food and biota was also contributed. ${ }^{69}$ In 1877 , timber-getter and businessman William Pettigrew made a presentation to the Queensland Philosophical Society in Brisbane outlining the useful qualities of native Queensland timbers. His presentation was based - as he admitted - almost entirely on information provided by the Aboriginal people he knew, his timber crew being initially all Indigenous people. ${ }^{70}$

\section{The influence of Aboriginal camps on urban history}

All of this evidence points to Aboriginal 'fringe camps' as more central to the story of the growth of colonial towns than is commonly accepted. Susanne Jones argued that a largely undocumented 'deep history' of Indigenous-European interaction probably underlies the development of most Australian urban settlements. ${ }^{71}$ Aside from historical and economic influences, did Aboriginal base camps influence the siting, components and design of Australian towns and suburbs? In south-east Queensland, the former campsites I was taken to by Aboriginal families were mostly located in current public reserves or parks, well within central business districts. This raises the question: which came first, park or camp?

Many site locations for south-east Queensland's historic camps are recorded in Colliver and Woolston's 'Aboriginals in the Brisbane Area' (1978) and John Steele's monumental Aboriginal Pathways (1983). Early Brisbane maps do not detail Aboriginal camp locations, but Local Studies units within Brisbane suburban libraries hold local reminiscences that help to place them. Old maps, early memoirs, newspaper reports and the insights of local history groups and archaeologists further expand the results. From this basis, I was able to locate some 100 historic Aboriginal camps within the Greater Brisbane area alone. ${ }^{72}$ Very few of these could have been 'single occasion' (or 'dinner') camps, as they are referenced over many decades, in different sources, yet always on the same location. Aboriginal informants advised me that at least six Brisbane camps were still functioning into the $1950 \mathrm{~s} .{ }^{73}$ In most cases, a park or some other reserve with a supply of water was the location. In the following discussion, examples from southern Queensland are considered in more detail.

69 Reynolds 1990.

70 Queenslander, 1 December 1877.

71 Jones 2009: 34, 41. See also McKenna 2002.

72 Kerkove 2015, funded by a Brisbane City Community Heritage grant.

73 Aird 2001; Yuggarapul Elder Des Sandy, pers. comm., Sandgate, April 2013. 


\section{Redcliffe}

Queensland's first European settlement was Redcliffe, 40 kilometres north of present-day Brisbane. In 1799, explorer Matthew Flinders made landfall below Redcliffe's Woody Point and proceeded 400 metres to what is now Clontarf. Here he encountered a vacant Aboriginal camp. ${ }^{74}$ Redcliffe was established as a penal colony in 1824, abandoned in 1825. Much later, in 1875, Clontarf was where Redcliffe's first urban settlement developed. Significantly, early residents found a vibrant Aboriginal camp at the same location that Flinders had recorded a camp. ${ }^{75}$ They describe its importance in the annual Aboriginal mullet run - groups coming from afar to fish and engage in dugong and turtle hunts and corroborees. ${ }^{76}$ Even in 1913, this was the regular camp for Sam Boama - the last Aboriginal man recorded living a 'traditional' life in Redcliffe. ${ }^{77}$ There are 12 references to this camp, spanning more than a century: in $1799,1823,1842,1843,1859,1875,1885,1887,1888$, 1890,1900 and $1913 .{ }^{78}$

Why Redcliffe's European settlement emerged next to an Aboriginal camp is revealed in early maps (Figure 2). They show that this area - known as 'Bell's Paddock' contained a set of freshwater reserves, created by lagoons and swamps. It was 'much bigger in those days ... It extended from Victoria Avenue to Thompson Crescent, taking in Donald and McLennan Streets' ${ }^{79}$ This area embraced all those that early colonists described as Aboriginal camps. ${ }^{80}$ Today, the area is a cluster of parks: Bell's Paddock, Bicentennial, Apex, Filmer, Woody Point and Crockatt.

Did the Aboriginal camps appear on account of the parks? Obviously not: Flinders's 1799 description and the other early pre-1875 references show that the camps long pre-date the parks. A much-used well near the Woody Point Park was purportedly of Aboriginal origin. There was another such well just north of the Clontarf Water Reserve. ${ }^{81}$ Thus the area's first wells also seem to have been Aboriginal.

\footnotetext{
74 Flinders in Steele 1972: 31-32.

75 'Blacks at Redcliffe', Courier Mail, 17 August 1935: 19; 'Redcliffe in the Early Eighties - Many Memories of the First Settlers', Sunday Mail, 9 March 1930: 21.

76 Courier Mail, 6 August 1935; Fairhill 1989: 13.

77 Box 1985: 3; Brisbane Courier, 5 December 1924.

78 Kerkhove 2015: 25-26; Courier Mail, 17 August 1935: 19.

79 Box 1985: 2.

80 Box 1985: 2; Gee 2009: 6; Courier Mail, 17 August 1935: 19.

81 At the bayside end of Albert Street, Margate. Richens 1978: 30.
} 


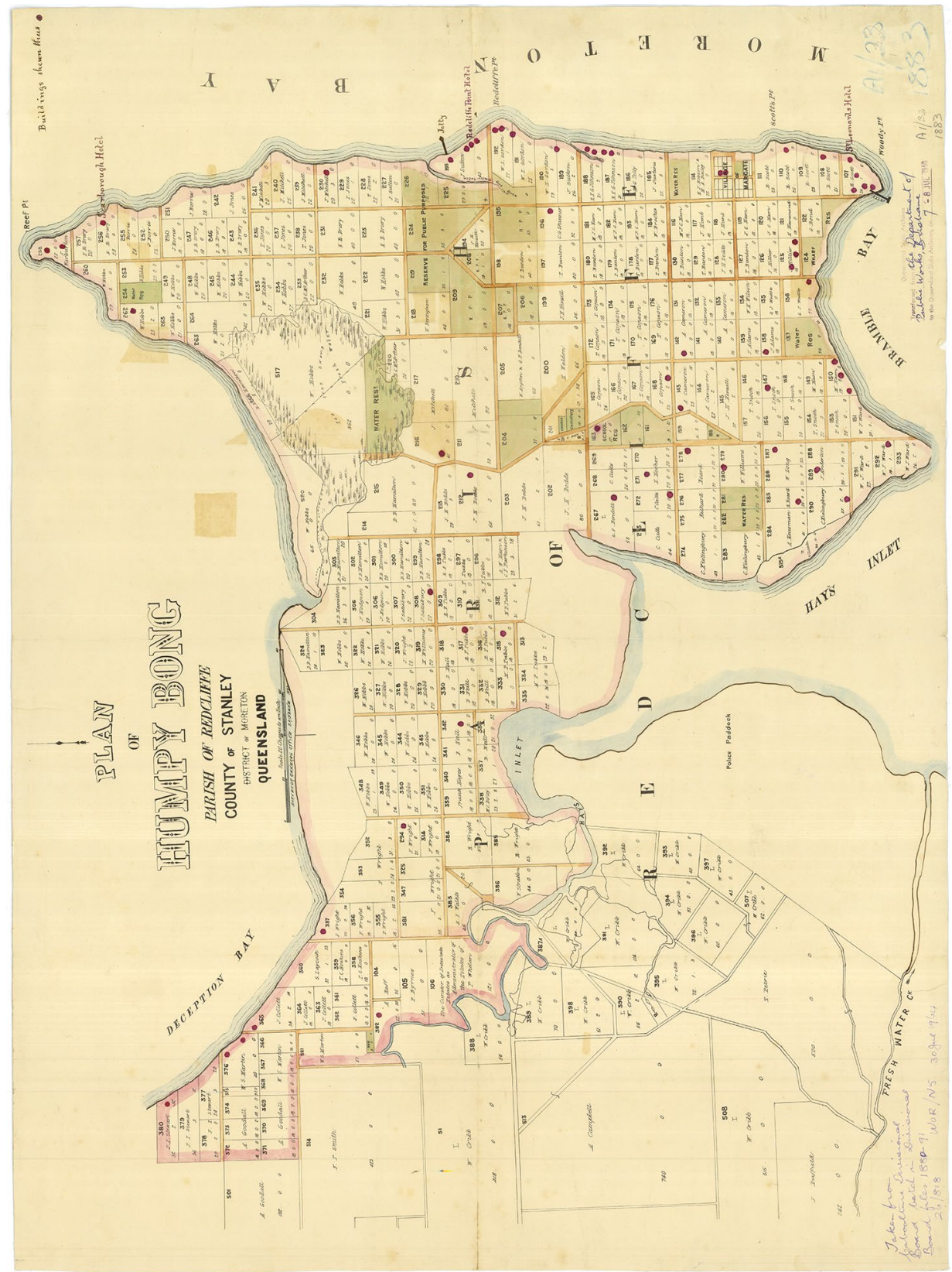

Figure 2: Redcliffe peninsula, showing water reserves (dark areas) associated with Aboriginal encampments.

Source: Queensland State Archives A1/32 1883. 
Further north lay the second colonial water reserve. In 1843, missionaries described an Aboriginal camp on this spot, decades before the reserve was declared. ${ }^{82}$ Today it is a park: Humpybong, at the heart of Redcliffe. ${ }^{83}$ Redcliffe's two other colonial water reserves were beside the only other recorded Aboriginal camping grounds of Redcliffe peninsula: on the very northern tip (Scarborough), and at the swampy 'neck' of Rothwell. ${ }^{84}$

The 'main business' of early Redcliffe seems to have grown from the camps' 'main business'. As mentioned, this area was the focus of the mullet run. The camps were renowned for quality oysters and mud crabs. Aboriginal hearths for processing and roasting shellfish were once common around Clontarf. ${ }^{85}$ European Redcliffe similarly won renown as a fishing, oystering, crabbing and boating resort. This could be a coincidence determined by the environment, except that early residents such as Parry-Okeden inform us that the Aboriginal residents were Redcliffe's first boating pilots and first sellers of fish and oysters. ${ }^{86}$ The European town developed in the 1880s-1920s, which suggests its raison d'etre was fed by intercultural exchange.

\section{Breakfast Creek}

In 1823 and 1824, explorers John Oxley and Alan Cunningham sought the best site for a Moreton Bay colony, the future Brisbane. They favoured 'Breakfast Creek', today's suburbs of Newstead, Ascot and Hamilton. Oxley promoted Breakfast Creek because here 'they [the Aborigines] are very numerous' ${ }^{87}$ Oxley viewed their villages as indicative of rich land. Cunningham was similarly delighted to find fresh water in the form of 'ten native wells' in the vicinity. Thus the location of Brisbane was chosen, as Oxley said, because it was 'not a half mile' from a cluster of Aboriginal camps: ${ }^{88}$

Numerous were the beaten paths of the wild aborigine. His several fireplaces showed me that this point of the river was numerously inhabited. ${ }^{89}$

These camps did not 'collapse' once settlement began. Rather, over the following decades we have continuous reports about them in local newspapers.

\footnotetext{
82 Nique and Rode 1843 in Gee c. 2010: 2.

83 Pat Gee, Redcliffe Local Studies, Redcliffe Shire Library, pers. comm., 12 June 2014.

84 'Interview with John Genn 3 October 2006', Gee c. 2010: 1; Queenslander, 7 December 1878: 311; Michael Strong, pers. comm., Sandstone Point, July 2014.

85 Richens 1978: 3; Gee c. 2010: 3; Sunday Mail, 4 June 1939, 6.

86 Sunday Mail, 9 March 1930: 21.

87 Oxley 16 September 1823 and 2 December 1823 in Steele 1972: 127.

88 Oxley 16 September 1824 in Steele 1972: 125.

89 Oxley 16 September 1824 in Steele 1972: 125.
} 
Ray Evans researched a violent police raid that took place here in 1861, in which the camps were burnt to the ground. ${ }^{90}$ He presumed this marked their end. However, this was not the first or last raid. The camps were destroyed by settlers and police at least seven times, ${ }^{91}$ but were continually rebuilt. ${ }^{92}$ At least one camp was still active into the 1890s, and a few Aboriginal residents lived close by in hostels as late as 1910-14. ${ }^{93}$ Families who claim descent from Brisbane and surrounding areas had ancestors living in these hostels. ${ }^{94}$

As the raids suggest, Breakfast Creek was a significant thorn in the side of colonists. For decades, there were reports of hostilities: raids on gardens, robberies, harassment, and counter-attacks by police and farmers. ${ }^{95}$ Alex Bond, a Kabi man, recalls his mother Penny Bond describing the area as a 'battle front'. Police regularly chased Aboriginal people across the creek each sundown. ${ }^{96}$ Tit for tat, camp residents treated settlers who ventured onto their side of the creek as fair game. Aboriginal defiance was the main reason for an 1850 petition from Breakfast Creek colonists demanding police protection. The area remained largely unsettled 32 years after Brisbane was established:

Between Breakfast Creek and Eagle Farm ... there still remains some dense patches [of scrub] ... it is at present the rendezvous of the Aboriginal tribes ... At these times they become a dangerous pest to the small farmers dwelling in that neighbourhood. ${ }^{97}$

Nevertheless, these camps were vital to Brisbane's supply of fish:

Until very recently the inhabitants of Brisbane depended mostly for a supply of fish upon the aborigines of this locality [Breakfast Creek], very much, no doubt, to the profit, in a pecuniary sense, of these sable sons of the soil..$^{98}$

Operating traditional fishing weirs and nets at the camps, the Aboriginal residents had sufficient surplus to trade and sell in town. ${ }^{99}$ Chas Melton witnessed 'a couple of hundred fish' procured 'in a few minutes' at Breakfast Creek. ${ }^{100}$ He states that the catches were sold door-to-door to Brisbane's 'housewives'. ${ }^{101}$ Today, the parks of Newstead, Crosby, Hamilton, Bartley's Hill and Oriel, and the Albion and Eagle Farm Raceways occupy the former camps.

\footnotetext{
90 Evans 1987: 311.

91 On July 1852, August 1859, December 1861, January 1862, October 1865, February 1867, November 1873.

92 Kerkhove 2015: 89-92.

93 Kerkhove 2015: 93.

94 Maroochy Barambah and Madonna Thomson, pers. comm., Brisbane, August 2016.

95 Kerkhove 2015: 89-92.

96 Bond and Kerkhove 2009; 'Brisbane's Historic Homes', Queenslander, 11 February 1932: 35.

97 Dawson 2009: 14.

98 Moreton Bay Courier, 17 August 1861.

99 Brisbane Courier, 29 March 1929.

100 Melton 1919: 347.

101 Melton 1915 [1924]: 58-59 (No. 83).
} 


\section{Victoria Park (York's Hollow)}

Another unacknowledged thorn in Brisbane's side lay above the city centre, around Victoria Park (Kelvin Grove and Spring Hill). This was 'York's Hollow' - windy, woody ridges that at times saw 700 to 1,000 Aboriginal residents in the $1840 \mathrm{~s}$ and $1850 \mathrm{~s},{ }^{102}$ making it similar in size to early Brisbane. ${ }^{103}$ Today, this remains the largest expanse of open space near Brisbane City: a park, a golf course, a tertiary institute and exhibition grounds. One of the original boundary roads lay south of the Aboriginal camps. Again, this was an area designated as a water reserve that became parkland. The area's many waterholes and springs were the main water supply for the northside of early Brisbane during the 1840 s to 1860 s. ${ }^{104}$

Denis Cryle and Rod Fisher presumed York's Hollow emerged as a 'fringe camp' during the 1840s and disappeared by $1860 .{ }^{105}$ However, my own finds of stone artefacts and oyster shell suggest it was occupied by the time of first settlement, if not before. A year before any European settlement (September 1824), Oxley reported being kept awake by the tumultuous noise of Aboriginals 'a mile above' his camp at Milton. ${ }^{106}$ A 'mile above' Oxley's camp would be roughly at today's Petrie Terrace. This was the location of 'Green Hills' camp, close to the former tournament grounds at Roma Street that the camps used. ${ }^{107}$ This might explain the noise.

Even if this was not the camp Oxley heard, we know York's Hollow existed by the convict period (1820s-1830s) as botanists visited it, ${ }^{108}$ and Tom Petrie, one of the earliest settlers, mentions its use. ${ }^{109}$ Neither did it disappear in 1860: a decade later, Archibald Meston visited 60 Aboriginals here. ${ }^{110}$ In the 1890 s, the location was a main centre for blanket giving. ${ }^{11}$ Still later, between the 1930s and 1950s, many Aboriginal families including the Fords and Rallahs lived in York's Hollow 'shanty town'. ${ }^{112}$

York's Hollow deaths, corroborees and tournaments were reported in Brisbane newspapers as part of the daily fare. White administrators were embroiled in disputes with the camps' occupants - to the extent of attacks (one by the 11th Regiment) and public executions. ${ }^{113}$

\footnotetext{
102 Brisbane Courier, 9 January 1933.

103 Brisbane had only 1,600 residents in 1849.

104 Greenwood and Laverty 1959: 81.

105 Cryle 1992: 32; Fisher 1992: $73 f$.

106 Steele 1972: 147.

107 Petrie 1904: 55.

108 Steele 1975: 219-20.

109 Petrie 1904: 160-61.

110 'Lost Tribes of Moreton Bay', Brisbane Courier, 19 June 1923: 8.

111 Brisbane Courier, 19 June 1923: 8; Blake 1987: 50.

112 Aird 2001: 29, 32-33.

113 Moreton Bay Courier, 3 February 1847: 2; Cryle 1990: 69-70; Connors 2015: 193.
} 


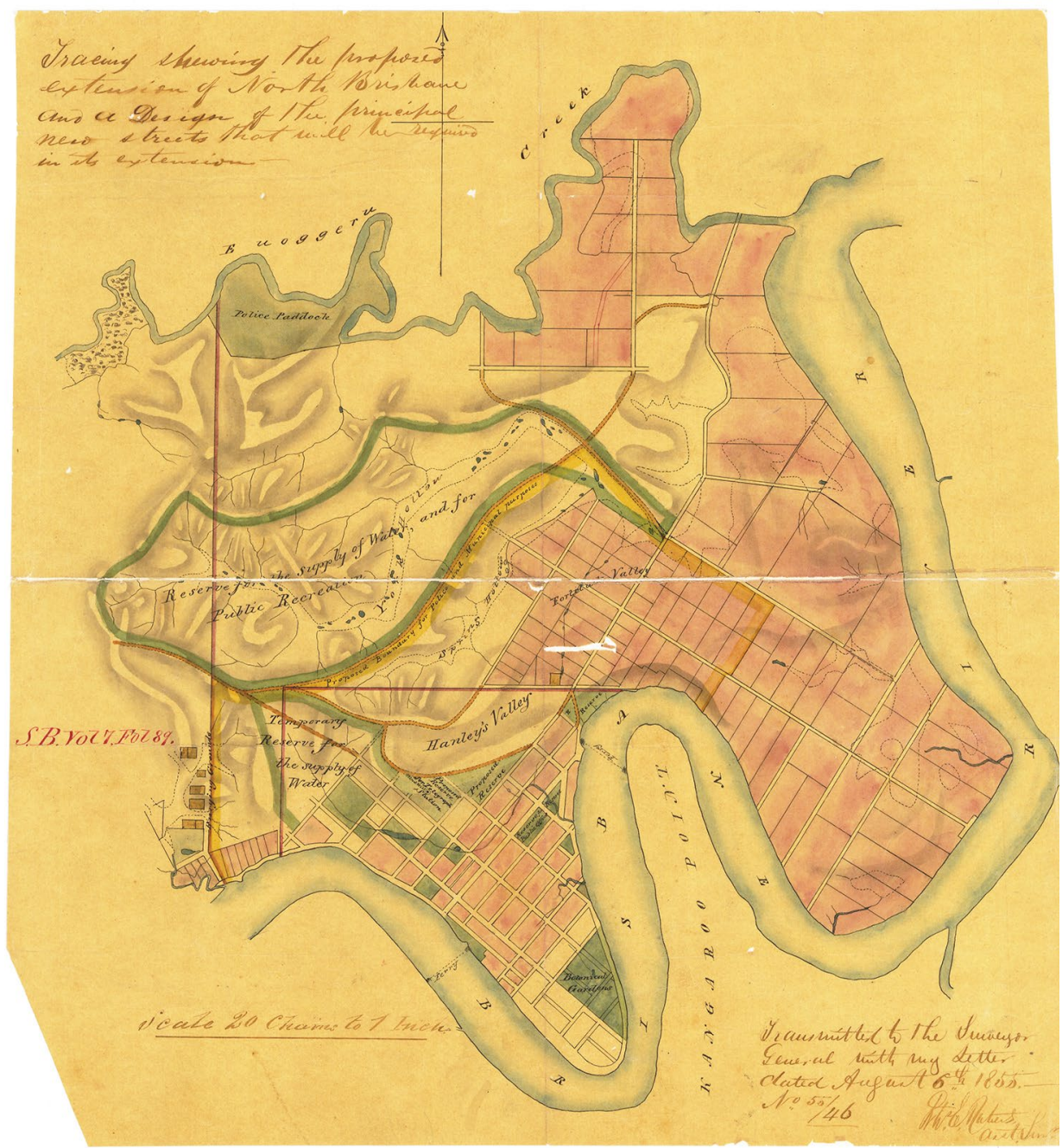

Figure 3: York's Hollow (thick outline) marked as 'Reserve for the Supply of Water and for Public Recreation' in 1855.

Source: Queensland State Archives.

The massive camp provided early Brisbane's gardeners, wood-choppers and domestic cleaners, and supplied brushwood (essential for domestic cooking and warmth), honey and ornamental plants and ferns. ${ }^{114}$ The latter seem to have influenced the development of Brisbane's distinctive 'bush houses' (decorative garden huts or veranda sections for displaying assorted fernery and orchids). Lord's 1930s history 
of Brisbane gardening tells us the tradition developed during the nineteenth century, being 'supplied with the most beautiful of their orchids, staghorns, ferns, etc. by the blacks' from scrubs behind York's Hollow camp. ${ }^{115}$

Later use of Victoria Park indicates further Aboriginal influence. Being the venue for spectacular intertribal sports and tournaments, York's Hollow drew European spectators. ${ }^{116}$ Its Aboriginal tournaments were recalled as 'stirring enough to arouse the admiration of the toughest larrikin'. ${ }^{117}$ Thus it is more than coincidental that Victoria Park's open woodlands became the venue for European sports and rifle-shooting. Eventually, the area hosted sports contests and shows - notably Queensland's annual Exhibition ('Ekka') - since 1876. From the 1910s to 1950s, the most popular aspect of this event were the Aboriginal boxing matches, and the 'Aboriginal Hall' where Aboriginal missions and reserves showcased their produce and crafts. ${ }^{118}$

\section{Nundah}

Queensland's first free (non-convict) settlement was a Moravian mission at 'German Station', Nundah (1838). It owes its existence and location to Aboriginal camps: the missionaries wanted to be close to potential converts, so they chose the crossroads of major pathways in the middle of several camps. ${ }^{119}$ Aboriginal elders granted them the spot called Tumbal ('hoop pine') - a forested knoll. ${ }^{120}$ When it became obvious that Aboriginal people were not becoming converts, government and mission funding dried up. This forced the German missionaries to focus on farming in order to survive. The mission sputtered to a gradual end, but it nevertheless initiated Queensland's first school, first dairy and first vegetable farms, all of which were for - and partly the work of - scores of Aboriginal people who attended the failing mission.

Despite the gradual demise of the mission, the camps persisted for many decades. During the 1910s, the site of the camps became what are still Nundah's main parks: Bishop, Mercer, Shaw and Kalinga. A huge inter-group corroboree was held at today's Mercer Park as late as $1903 .{ }^{121}$ Even in the 1940 s to 1950 s, Kalinga Park was home to a shanty town that included Aboriginal families. ${ }^{122}$

\footnotetext{
115 McCallum 2004: 4.

116 Brisbane Courier, 3 June 1922.

117 Sunday Mail, 21 October 1928.

118 Scott and Laurie 2008: 44, 162-64, 226.

119 Cleary 2002; Australian, 13 December 1838.

120 Queenslander, 13 December 1902.

121 Nunn et al. 1998: 6.

122 Sunday Mail, 1 August 1954.
} 

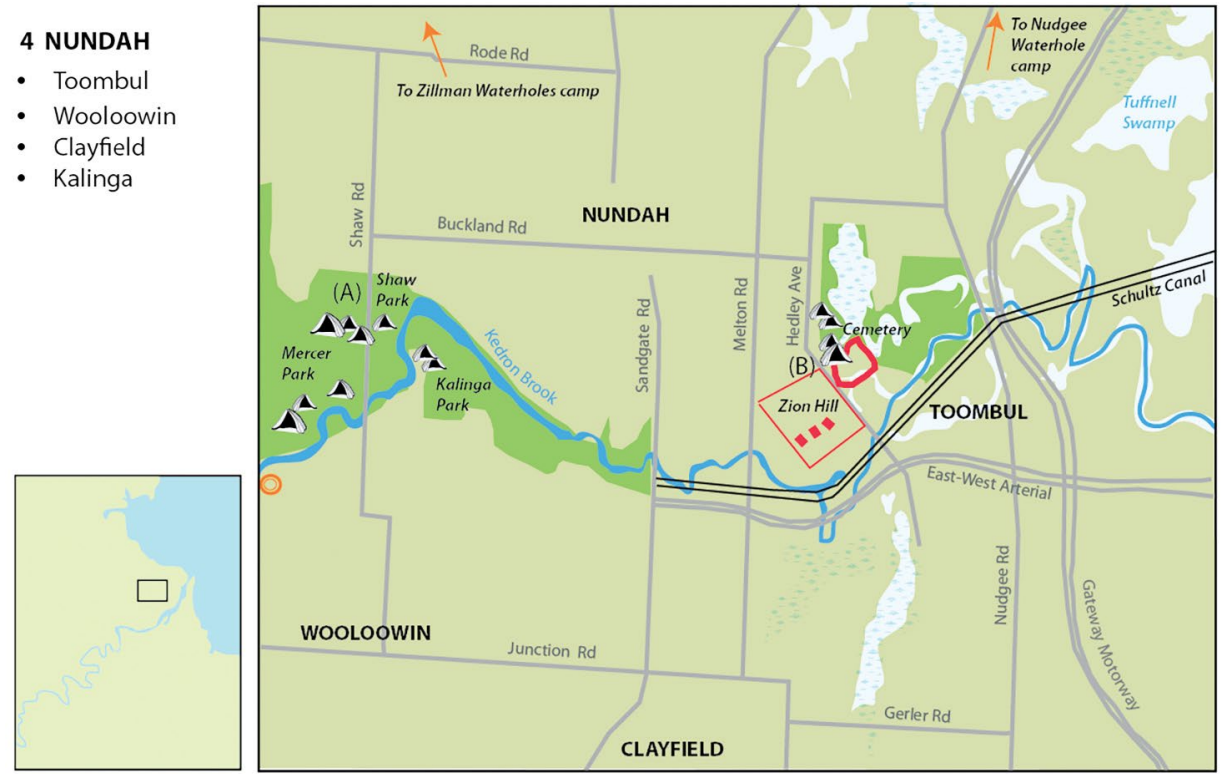

Figure 4: Nundah showing the correlation between location of Aboriginal camps (triangular hut shapes), parks (green shaded areas surrounding Kedron Brook and cemetery) and the German mission of Zion Hill (red areas).

Source: Author and Turnstone Archaeology.

\section{Wynnum}

Wynnum's Indigenous roots were never denied. The area was first remembered as a large 'black's camp'. ${ }^{123}$ Early residents stated they knew their Bayside hamlet was named by Aboriginal people after pandanus (win-nam) - a food source. ${ }^{124}$ Tom Petrie, an early visitor, described Wynnum as the Aboriginal camp for launching expeditions to hunt turtle, dugong and flying fox on the neighbouring islands. ${ }^{125}$ There were advertisements for Aboriginal boating and fishing excursions - including the traditional turtle and dugong hunts. ${ }^{126}$

$123 \mathrm{Mr}$ Port in Wynnum Library 1995: 3.

124 Gough in Wynnum Library 1995.

125 Petrie 1904: 89; see also 'Various Fishing Methods', Queenslander, 9 August 1902: 291.

126 Australasian Sketcher with Pen and Pencil, 17 May 1888. 
European settlement first appeared at North Wynnum (around the mouth of Wynnum Creek) as a fishing-related adjunct to the Aboriginal camp. ${ }^{127}$ By 1908, Wynnum was a thriving town and the old camp was transformed into public parks (Elanora Park and Greene's Park). ${ }^{128}$ However, locals persisted in referring to this area as 'Blacks Camp' in the 1920s-1940s. ${ }^{129}$

\section{Nambour}

Nambour today is the administrative centre for the Sunshine Coast Regional Council. The accepted history is that the town was 'founded' or settled in 1870 when Matthew Carroll Senior set up a hut on the town's Petrie Creek. The town was purportedly named after a farm. ${ }^{130}$ However, eight years earlier (1862), a map of this area already shows 'Nambour' marked where the town is now. The map was produced by William Pettigrew, an early timber-getter. According to Pettigrew's diary, 'Nambour' constituted the grassy flats by Petrie Creek, which he coveted for running cattle, but could not use as too many Aboriginal people were there, frightening the herd. ${ }^{131}$ Also in 1862, pioneer Tom Petrie visited this area (hence 'Petrie's Creek'). He similarly mentions a camp on the creek - a great corroboree centre where even groups from the distant interior stayed. ${ }^{132}$ Thus, Nambour camp certainly preceded Nambour town.

In fact, the camp seems to have been the reason for establishing a town. Petrie visited solely to recruit a team for timber work. Some 40 individuals (including their wives and children) elected to join him. For the next decade, these were the main timberworkers around the Sunshine Coast and Wide Bay. ${ }^{133}$ Mathew Carroll only moved into the Sunshine Coast under a contract to cut timber. ${ }^{134} \mathrm{He}$ shifted from the beach to Petrie's Creek to assist Pettigrew's and Petrie's timber work. By 1865, Pettigrew had arranged for logs to be dragged to what is now Nambour Showgrounds at the Petrie Creek camp. ${ }^{135}$ This was where Mathew Carroll chose to settle. Mathew Carroll Junior describes the camp:

\footnotetext{
127 'Early Wynnum and Manly', Wynnum Manly Historical Society, n.d. (c. 2015), www.wmhs.org.au/wpcontent/uploads/2015/11/Early_Wynnum_Manly.pdf (accessed 14 October 2018). See also Parke 2012: 18.

128 Wynnum North State Primary School Centenary Committee 1982: 13.

129 Port in Wynnum Library 1995: 3.

130 'Nambour's Beginnings - A Reminiscence, Part I', St Joseph's Magazine, 8 February 1934: 2.

131 Taiton 1976: 103.

132 'Tom Petrie’s Reminiscences', Queenslander, 24 May 1902: 1132; Petrie 1904: 23.

133 Kerkhove 2014: 56-57, 61.

134 Kerr 1998.

135 Pettigrew 1862-1865.
} 
The show ring [site] was a favourite camping ground [for the blacks] and there they used to stay for weeks at a time ... Often have I seen hundreds of mia-mias erected on the showgrounds, perhaps most frequently at bunya time, every three years. ${ }^{136}$

Carroll explains that as his family were the only white residents, his playmates as a child were Aboriginal children who - like him - became involved with the timber industry:

We were often much aided by the aborigines, our playmates of earlier days, who knew where the rich timber patches were in the scrubs and led us to them. Some of the blacks themselves made first-class bullock-drivers and fine timber-cutters. ${ }^{137}$

The Nambour Showgrounds is still within Nambour's central business district.

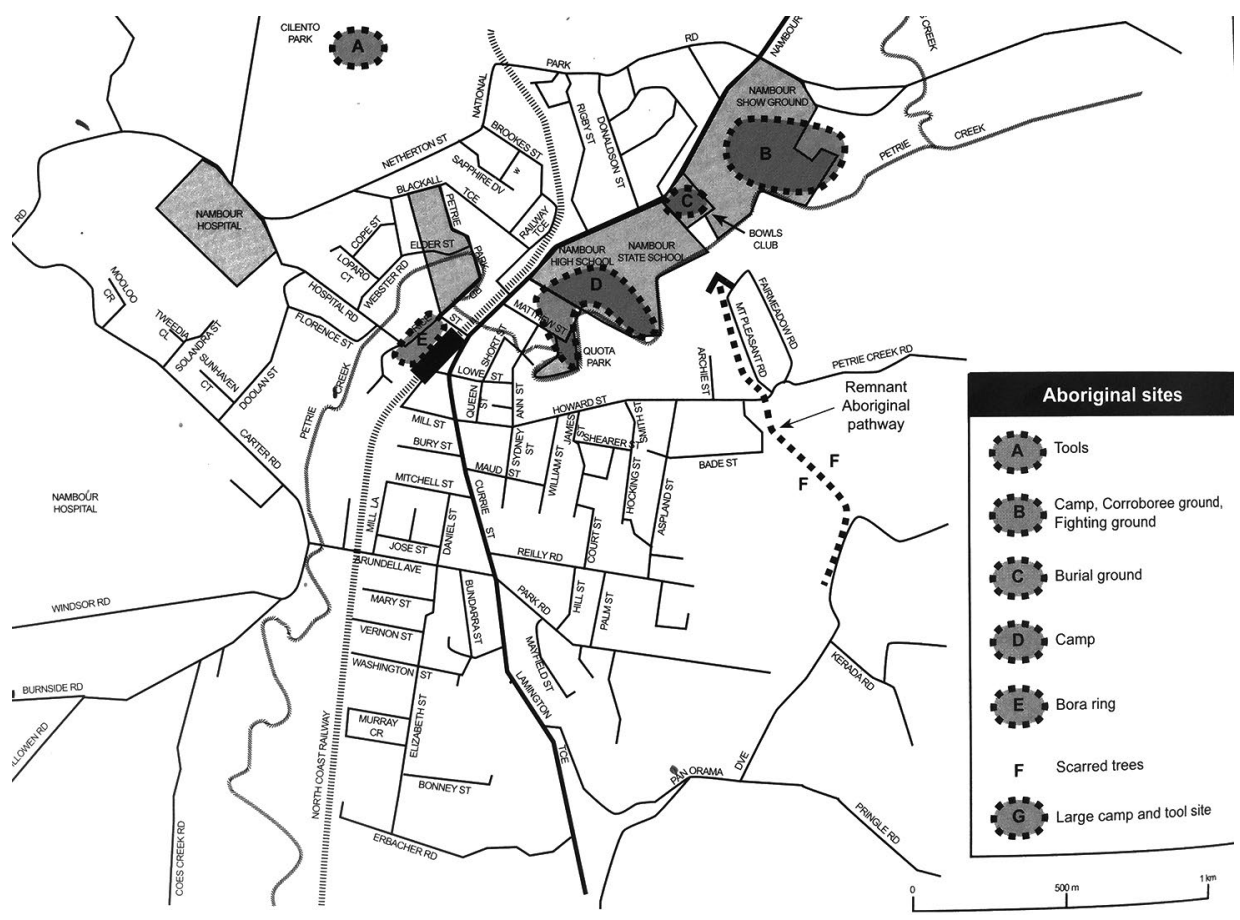

Figure 5: Relationship between traditional Aboriginal camps and sites of Nambour and the current town plan.

Source: Author, 2009. 


\section{Bli Bli}

Officially, the history of Bli Bli on the Sunshine Coast begins in the 1910s. Prior to this (1880s), the area had just a single homestead. ${ }^{138}$ However, opposite that homestead and the heart of today's Bli Bli town lies Muller Park. Early residents recall this as:

once a large aboriginal settlement, acres of which are still covered with the shells of oysters and other fish which must have comprised a good part of the diet of those ancient inhabitants ... Old settlers tell of a large encampment of blacks at this locality. ${ }^{139}$

The account goes on to describe the many axes, grindstones and tools for processing shellfish that farmers would plough up there. Bli Bli camp persisted until 1917.140 There are Aboriginal people, such as the Jones family, whose ancestors are recorded living at that camp and who still live there. Ironically, today white residents dispute this heritage, ridiculing Aboriginal people's attempts to fight inappropriate development of Muller Park. ${ }^{141}$

\section{Maroochydore}

Maroochydore on the Sunshine Coast is said to have emerged in 1912 at Cottontree (Maroochy Heads), developing from 1890s holiday camps run by the Salvation Army. ${ }^{142}$ That 'point of origin' is even now a caravan park. These holiday camps founded the region's beach tourism. ${ }^{143}$ What is missing from this narrative is the fact that the church camps were only established because the Salvation Army was greatly alarmed at the moral laxity of the Europeans, Pacific Islanders and Aboriginals already camping here. ${ }^{144}$ Since the 1870 s, timber was rafted from Coolum Creek, Nambour and Bli Bli to Cottontree by Pettigrew's Indigenous team. They camped at Chambers Island and Picnic Point in Maroochydore. ${ }^{145}$ Maroochydore's first boat and fishing tours also seem to have been run by local Aboriginal families, such as the Balls. ${ }^{146}$ In fact, Cottontree was already an ancient residential area.

138 Nambour Chronicle and North Coast Advertiser, 22 July 1927.

139 Nambour Chronicle and North Coast Advertiser, 22 July 1927.

140 The Telegraph, 23 May 1917.

141 'Aboriginal elder calls for calm in rowing club dispute', Sunshine Coast Daily, 27 May 2015, www.sunshine coastdaily.com.au/news/aboriginal-elder-calls-for-cordial-result-in-rowin/2652050/ (accessed 16 October 2018).

142 Gittins 1994.

143 Gregory 1991: 81.

144 Gittins 1994: 15.

145 Cubby 1976: 5.

146 Chronicle and North Coast Advertiser, 4 September 1903: 5. 
In 1844 - before any white presence - the explorer Bracewell described an Aboriginal camp of over 80 persons at Maroochy Heads. ${ }^{147}$ Ian McNiven's excavations found that, from 500 years ago until colonial times, Maroochy Heads was a favoured site for exploiting estuarine shellfish (oyster, cockle, whelk) and processing bungwall (a swamp tuber). ${ }^{148}$

Thus it would be more correct to say that Maroochydore began as a shellfishharvesting camp. Shellfishing was woman's work (they would travel through the area's mangrove islands in small canoes to gather oysters). Their presence made Maroochydore attractive to the mostly male Aboriginal, Islander and European workers who camped here. As this resulted in Aboriginal, Aboriginal-Islander and Aboriginal-European liaisons, one of the Salvation Army's first acts at Cottontree was conducting beachside marriages. ${ }^{149}$

\section{Ipswich}

Queen's Park is the centrepiece of Ipswich City, surrounded by heritage architecture and sporting a public zoo. What is less known is that the site is a revered Aboriginal camp, bora (ceremonial) site and tournament area. ${ }^{150}$ Ipswich City Council formally acknowledges this in its Land Management Plan. ${ }^{151}$

In 2011, an archaeological survey revealed many Aboriginal stone artefacts at Queen's Park, indicating intensive Aboriginal occupancy before settlement. Limestone Ridge (a dominant feature of the park) was found to be a set of chalcedony quarries. Long before European presence, these stimulated trade, ceremony and tournaments between surrounding clans, explaining why a major camping ground developed on this site. ${ }^{152}$ Also before settlement, the explorer Cunningham spotted a shipworm (Teredo species) 'farm' being operated near what is now Queen's Park. ${ }^{153}$ Such 'farms' (artificial piles of logs regularly harvested for Teredo) were constructed near the junction of creeks and rivers (such as the Queen's Park site), marking popular locations for major base camps. ${ }^{154}$

European history of Ipswich began with a convict lime-burning outpost at what is now 2 Thorn Street. This is next to Limestone Hill (Queen's Park), which means the city's colonial birthplace sits beside the ancient camp.

\footnotetext{
147 Steele 1983: 178.

148 McNiven 1989: 45-48.

149 Gittins 1994: 15f.

150 Turnstone and Jagera Daran 2011: 39-40.

151 Ross Planning 2010: 10.

152 Turnstone and Jagera Daren 2011: 61-62.

153 Cunningham 1827 in Turnstone and Jagera Daran 2011: 30

154 Queenslander, 9 August 1902: 291. Petrie here identifies teredo farms at creek-river junctions at Mooloolaba,

Petrie and other sites known to have had large encampments.
} 
Accounts throughout the nineteenth century give us ample proof that the Queen's Park area remained a large and thriving Aboriginal settlement: 'their camp being in a portion of the park near Limestone Hill'. ${ }^{155}$ Frequent, large inter-group tournaments occurred at 'Limestone Hill', ${ }^{156}$ indicating the site retained its traditional use. It was only in the 1880s-1890s that Aboriginal residents of Queen's Park were fully evicted. The evictors were aware that the site was the main living area of the Aboriginal population:

other than the camp in Queens Park, they did not have a home to go to. It would seem that their presence in Queens Park not only evoked a sense of compassion but also some consternation and perhaps embarrassment. ${ }^{157}$

The evicted population became the core of Deebing Creek Mission, 8 kilometres south. ${ }^{158}$ Thus the city's spatial origins were obscured by a forced removal.

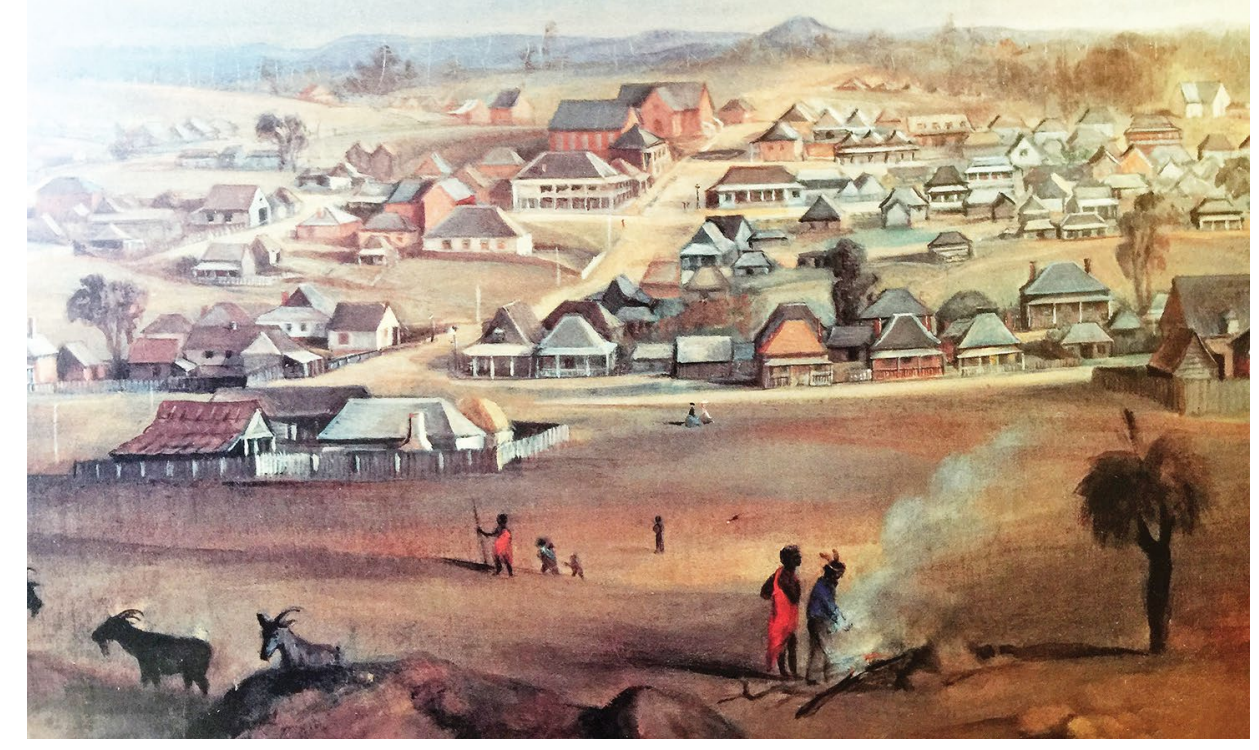

Figure 6: View from Limestone Ridge in Queen's Park, Ipswich, showing continued Aboriginal presence in the 1860s (William Francis Emery, View of Ipswich from Limestone Hill, 1861/62, oil on canvas, Gift of Mr Les Thomas, 1986). Source: Ipswich Art Gallery Collection. 


\section{Barcaldine}

In 1846, explorer Thomas Mitchell placed a dot on his map at a spot he called 'Lagoon Creek'. Above this, he scribbled 'native camp'. Below, he added 'tribe of natives'. ${ }^{159} \mathrm{He}$ was 600 kilometres from any white settlement. Seventeen years later, 'Lagoon Creek Railway Station' was built exactly where Mitchell placed his 'native camp' dot. Twenty years after that, Barcaldine town was founded - again, at Lagoon Creek.

Today, Lagoon Creek is mostly known as the historic location of the Shearers' Strike camps (1891). What is less known is Lagoon Creek's status as the Aboriginal camp in colonial times, and that it is where Aboriginal people of the area tend to live still. ${ }^{160}$ An abundance of flaked artefacts clearly demonstrates the antiquity of the site at Lagoon Creek. ${ }^{161}$ They help to show that Barcaldine is Lagoon Creek Aboriginal camp, enduring from prehistory to the present.

\section{Conclusion}

When Patricia Bourke surveyed post-contact camping grounds in Darwin, she discovered she was probably the first person to do so:

[My survey] highlighted the almost complete lack of [archaeological] knowledge related to distribution or frequency of more recent 'contact period' sites ... archaeological work historically has focused on sites of Holocene or earlier age .... [resulting in] a dearth of archaeological research focused on more recent sites in urban areas. ${ }^{162}$

This situation is widespread and highlights the incomplete state of knowledge of historic Aboriginal camps.

It has been presumed that Aboriginal camps were too transient, too disrupted, too fragile or too disconnected to influence urban development. This has led to situations such as the 2014 Musgrave Park tent embassy eviction, wherein it was debated whether Aboriginal people were reclaiming their own place or illegally squatting. By contrast, more than 80 years ago, Queenslanders accepted that settlers had usurped Aboriginal sites:

162 Bourke 2005: 54-55. 
the bold adventurer, having marked with an axe on the four corner trees the boundary of his selection of 100 square miles falls the first trees for his horse yard and splits the first slabs for his home, with rifle holes in the walls to keep off the blacks that for years will dispute with him possession of the waterhole which is his headquarters. ${ }^{163}$

This paper argues that although the history of dispersal is undeniable, many Aboriginal camps endured on their traditional locations, maintaining vibrant communities well into the modern era, and impacting the physical configuration of our suburbs and towns.

Long before European discovery, Australia had a populated cultural landscape. It seems logical that patterns of Indigenous occupancy helped define features of urban Australia. ${ }^{164}$

Many urban roads follow Aboriginal pathways. ${ }^{165}$ Many suburban placenames equate with ancient living areas. ${ }^{166}$ In southern Queensland, water reserves and green spaces were often relics of camping grounds, and central business districts often grew from colonial interactions with important Aboriginal base camps.

Who then were the 'fringe dwellers'? The first homesteads and hamlets often occupied the fringes of Aboriginal water sources and the fringes of Aboriginal base camps. Thus European settlements might be classed as 'fringe camps'. Kerry Jones, a representative of one of the Kabi Kabi families on the Sunshine Coast, said to me that his people had been vital to 'kick-starting' towns and industries 'but no one believes us'. ${ }^{167}$ Whether recognised or not, Australia's urban geography has undeniable Aboriginal foundations.

\section{References}

\section{Archival sources}

John Oxley Collection, State Library of Queensland

Milne, Rod 1993, 'Dahs and Bahs: Aboriginal Placenames of Southern Queensland', Brisbane, $\mathrm{n} / \mathrm{p}$.

\section{New South Wales State Archives}

NSW Archives, NRS 906 (1846-1856), 4/7153: 2, 'Annual reports on state of the Aborigines', 22 September 1852.

163 Courier Mail, 3 March 1934.

164 Head 2000.

165 Kerwin 2010.

166 Milne 1993.

167 Kabi elder Kerry Jones, pers comm., Noosa, February 2016. 
Queensland State Archives

QSA, AIA Series, c. 1850.

QSA, QDNR MT12, Item ID 714302, Henry Wade, 1844, Map of Environs of Brisbane Town

\section{Redcliffe Local Studies Unit, Redcliffe City Library}

Box, Kathy 1985, Redcliffe Historical Society, 'Sam Bell (Boama) - Last of His Tribe' MSS

Gee, Pat c. 2010, 'Aboriginal Notes'

\section{Royal Historical Society of Queensland (Welsby Collection)}

Melton, Chas 1915 [1924], 'When Wolloongabba was Wattle-scented', Melton Cuttings Book MSS

Pettigrew, William M. 1862-1865, Diary - Extracts from William Pettigrew’s Diary MSS

\section{Sunshine Coast Heritage Library, Nambour}

Taiton, Rev. J. 1976, Marutchi - Early History of the Sunshine Coast MSS

\section{Wynnum Local Studies Unit, Wynnum Library}

Wynnum Library 1995, 'Memories of Wynnum' (file)

\section{Newspapers and Journals}

The Australasian Sketcher with Pen and Pencil

The Australian

Brisbane Courier

Chronicle and North Coast Advertiser

The Conversation

Courier Mail (Brisbane)

Moreton Bay Courier

Nambour Chronicle and North Coast Advertiser

Queenslander (Brisbane)

The Stringer

Sunday Mail

Sunshine Coast Daily

The Telegraph (Brisbane)

The Week (Sydney) 


\section{Secondary sources}

Aird, Michael 2001, Brisbane Blacks, Keeaira Press, Southport, Queensland.

Anderson, Kay and Jane M. Jacobs 1997, 'From urban Aborigines to aboriginality and the city: One path through the history of Australian cultural geography', Australian Geographical Studies 35(1): 12-22.

Blake, Thom 1987, 'Excluded, exploited, exhibited: Aborigines in Brisbane 1897-1910', in Brisbane: Aboriginal, Alien, Ethnic, Brisbane History Group Papers no. 5, Brisbane History Group Inc., Brisbane: 49-58.

Bond, Alex and Ray Kerkhove 2009, The Statesman, the Warrior and the Songman, Interactive Community Planning Inc., Nambour, Queensland.

Bourke, Patricia M. 2005, 'Identifying Aboriginal Contact Period sites around Darwin long past due for native title?', Australian Aboriginal Studies 1: 54-65.

Buchan, Bruce 2001, 'Subjecting the Natives: Aborigines, property and possession under early colonial rule', Social Analysis: The International Journal of Social and Cultural Practice 45(2): 143-62.

Byrne, Denis 2003, 'The ethos of return: Erasure and reinstatement of Aboriginal visibility in the Australian historical landscape', Historical Archaeology 37(1): 73-86. doi.org/ 10.1007/BF03376593.

Cleary, Denis 2002, 'Foreword', in From Pioneering Days - Nundah, Northgate, Virginia, Nundah and Districts Historical Society, Nundah, Queensland.

Coleman, Julia 1979, 'Fringe camps and the development of Aboriginal administration in Central Australia', Social Analysis 2: 38-57.

Coleman, Julia 1982, 'A new look at the north coast: Fish traps and villages', in Coastal Archaeology in Eastern Australia: Proceedings of the 1980 Valla Conference on Australian Prehistory, Sandra Bowdler (ed.), Department of Prehistory, Research School of Pacific Studies, Australian National University, Canberra: 1-10.

Colliver, Frank and F.P. Stanley Woolston 1978, 'Aboriginals in the Brisbane area', Brisbane Retrospective, Library Board of Queensland, Brisbane.

Connors, Libby 2015, Warrior: A Legendary Leader's Dramatic Life and Violent Death on the Colonial Frontier, Allen \& Unwin, Sydney.

Coutts, P.J.F. 1966, 'Features of prehistoric campsites in Australia', Mankind - Australian Anthropological Society 6(8): 338-46. doi.org/10.1111/j.1835-9310.1966.tb00371.x.

Cowlishaw, Gillian 1988, 'Australian Aboriginal studies: The anthropologists' accounts', Sydney Studies in Society and Culture 4: 63-79.

Cryle, Denis 1992, 'Snakes in the grass', in Brisbane - The Aboriginal Presence 1824-1850, Rod Fisher (ed.), Brisbane History Group Papers no. 11, Brisbane History Group Inc., Brisbane: 69-79. 
Cubby, Craig 1976, Campbellville and Cedar Days: An Outline History of the Former Southeast Queensland Sawmilling Township of Campbellville and Pioneers of the Associated Timber Industry, Department of Forestry, Brisbane.

Dawson, Chris (comp.) 2009, Random Sketches by a Traveller Through the District of East Moreton, Inside History Series, Boggo Road Gaol Historical Society, Fairfield Gardens, Queensland.

Egloff, Brian, Michael O'Sullivan and Juliet Ramsay 1991, 'Archaeology of the 1891 Shearers' War: The main strike camp at Barcaldine, Queensland', Australian Historical Archaeology 9: 64-75.

Evans, Ray 1984, 'Kings' in brass crescents: Defining Aboriginal labour patterns in colonial Queensland', in Indentured Labour in the British Empire, 1834-1920, Ray Evans and Kaye Saunders (eds), Croom Helm, London: 180-200.

Evans, Ray 1987, 'Wanton Outrage', in Radical Brisbane: An Unruly History, Ray Evans and Carole Ferrier, Vulgar Press, Carlton: 80-89.

Evans, Ray 1999, “'Steal away": The fundamentals of Aboriginal removal', Queensland Journal of Australian Studies 23(61): 83-95. doi.org/10.1080/14443059909387477.

Evans, Ray, Kay Saunders and Kathryn Cronin 1975, Exclusion, Exploitation and Extermination: Race Relations in Colonial Queensland, Australia and New Zealand Book Company, Sydney.

Fairhill, Patricia 1989, Ningi Ningi - Our First Inhabitants, Redcliffe Historical Society, Redcliffe, Queensland.

Feehely, Dan 1997, The Fire People 1830s-1930s: A History of the Burra - the Aboriginal People of the Eastern Darling Downs, Dan Feehely, Toowoomba.

Fisher, Rod 1992, 'From Depredation to Degradation - The Aboriginal experience at Moreton Bay 1842-1860', in Brisbane - The Aboriginal Presence 1824-1850, Rod Fisher (ed.), Brisbane History Group Papers no. 11, Brisbane History Group Inc., Brisbane: 31-46.

Gee, Patricia 2009, Woody Point Jetty Memories 1882-2008, Moreton Bay Regional Council, Strathpine, Queensland.

Gittins, Kate 1994, The Salvation Army Nambour Corps: 100 Years of Service of the Sunshine Coast, Salvation Army Centenary Committee, Nambour, Queensland.

Godwin, Luke and Scott L'Oste-Brown 2002, 'A past remembered: Aboriginal 'historical' places in central Queensland - yambas', in After Captain Cook: The Archaeology of the Recent Indigenous Past in Australia, Rodney Harrison and Christine Williamson (eds), AltaMira, Walnut Creek: 191-212.

Goodall, Heather 1999, 'Telling country: Memory, modernity and narratives in rural Australia', History Workshop Journal 47: 160-90. doi.org/10.1093/hwj/1999.47.160. 
Greenop, Kelly 2008, 'Inala traditions: People, places and history in urban Indigenous communities', Traditional Dwellings and Settlements Working Paper Series, no. 216, International Association for the Study of Traditional Environments, Berkeley: 6-48.

Greenop, Kelly and Paul Memmott 2006, 'Contemporary urban Aboriginal place values', in Brisbane, Past Matters: Heritage, History and the Built Environment: Proceedings from the 8th Australasian Urban History/Planning History Conference, Wellington Campus, New Zealand, 9-11 February, 2006, New Zealand School of People, Environment and Planning, Massey University, Palmerston North, New Zealand: 157-70.

Greenwood, Gordon and John Laverty 1959, Brisbane 1859-1959: A History of Local Government, Council of City of Brisbane, Brisbane.

Gregory, Helen 1991, Making Maroochy, Maroochy Shire Council and Boolarong Press, Nambour, Queensland.

Habermann, David 2003, Deebing Creek and Purga Missions 1892-1948, Ipswich City Council, Ipswich.

Hall, Jay 1982, 'Sitting on the crop of the bay: An historical and archaeological sketch of Aboriginal settlement and subsistence in Moreton Bay, southeast Queensland', in Coastal Archaeology in Eastern Australia, Occasional Papers in Prehistory no. 11, Department of Prehistory, Research School of Pacific Studies, The Australian National University, Canberra: $79-95$.

Hall, Jay and Ian Lilley 1987, 'Excavation at the new Brisbane Airport site (LB: C69): Evidence for early mid-Holocene coastal occupation in Moreton Bay, SE Queensland', Queensland Archaeological Research 4: 54-79.

Head, Lesley 2000, Second Nature: The History and Implications of Australia as Aboriginal Landscape, Syracuse University, Syracuse.

Henry, Rosita 1999, 'Practising Place, Performing Memory: Identity Politics in an Australian Town - the "Village in the Rainforest", PhD thesis, James Cook University.

Hinkson, Melinda 2002, 'Exploring “Aboriginal” sites in Sydney: A shifting politics of place', Aboriginal History 26: 62-77.

Hinkson, Melinda and Benjamin Smith 2005, 'Introduction: Conceptual moves towards an intercultural analysis', Oceania 75(3): 157-66. doi.org/10.1002/j.1834-4461.2005. tb02877.x.

Hock, Isabel 1990, Barcaldine 1846-1986, 2nd edition, Barcaldine Shire Council, Barcaldine, Queensland.

Hunter, Ernest 1991, 'Out of sight, out of mind-2. Social and historical contexts of selfharmful behaviour among Aborigines of remote Australia', Social Science and Medicine 33(6): 661-71. doi.org/10.1016/0277-9536(91)90020-D.

Irish, Paul 2017, Hidden in Plain View: The Aboriginal People of Coastal Sydney, NewSouth Publishing, Sydney. 
Irish, Paul and Michael Ingrey 2013, 'Marking their footsteps: Aboriginal people and places in nineteenth-century Sydney', in Exploring Urban Identities and Histories, C. Hansen and K. Butler (eds), AIATSIS Research Publications, Canberra: 75-90.

Johnston, Ross 1988, Brisbane: The First Thirty Years, Boolarong, Spring Hill, Queensland.

Jones, Susanne M. 2009, 'The Anatomy of a Relationship: Doing Archaeology with an Indigenous Community on a Former Mission - A Case Study at Point Pearce, South Australia', BA (Hons) thesis, Department of Archaeology, School of Humanities, Flinders University of South Australia.

Kabaila, Peter R. 2012, 'Aboriginal camps around Yass - extracts from survival legacies', Canberra Historical Journal: 1-18.

Kerkhove, Ray 1985, 'West End to Woolloongabba: The Early and Aboriginal History of a District', Foundation for Aboriginal and Islander Research Action, Brisbane.

Kerkhove, Ray 2008, 'Report to QSNT Brisbane: Bidjara Connections in the Aramac, Barcaldine and Adavale Regions', Interactive Community Planning Inc., Nambour, Queensland.

Kerkhove, Ray 2013, 'Aboriginal trade in fish and sea foods in 19th century SE Queensland', Queensland Review 20(2): 144-56. doi.org/10.1017/qre.2013.17.

Kerkhove, Ray 2014, 'The Indigenous timber-getters on the Sunshine Coast', in A History of Trees in Buderim: Research and Preliminary Inventory, Meredith Walker, Buderim Historical Society, Buderim: 54-61.

Kerkhove, Ray 2015, Aboriginal Campsites of Greater Brisbane: An Historical Guide, Boolarong Publishing, Salisbury, Queensland.

Kerr, John 1998, Forest Industry Heritage Places Study: Sawmills and Tramways - South Eastern Queensland, Department of Forestry, Brisbane.

Kerwin, Dale 2010, Aboriginal Dreaming Paths and Trading Routes: The Colonisation of the Australian Economic Landscape, Sussex Academic, Eastbourne.

Kidd, Ros 2000, The Aboriginal History of Princess Alexandra Hospital Site Brisbane, Diamantina Health Care Mission Association, Brisbane.

Leichhardt, Ludwig 1842-1844 [2013], The Leichhardt Diaries. Early Travels in Australia During 1842-1844, Tom Darragh and Rob Fensham (eds), Queensland Museum, South Brisbane.

Lilley, Ian 1984, 'Late Holocene subsistence and settlement in subcoastal south-eastern Queensland', Queensland Archaeology Research 1: 8-32.

Loos, Noel 1982, Invasion and Resistance: Aboriginal-European Relations in North Queensland 1861-1897, Australian National University Press, Canberra. 
Lothian, Kathy 2007, 'Moving blackwards: Black Power and the Aboriginal Embassy', in Transgressions: Critical Australian Indigenous Histories, Ingereth Macfarlane and Mark Hannah (eds) (Aboriginal History Monograph 16), ANU E Press and Aboriginal History Inc., Canberra: 19-34.

Lourandos, Harry 1977, 'Aboriginal spatial organisation and population: South-western Victoria reconsidered', Archaeology and Physical Anthropology in Oceania 12: 202-25.

McCallum, Beres 2004, Windsor Wakens: Residents and Notables of the 1860s, Windsor \& Districts Historical Society, Lutwyche, Queensland.

McKenna, Mark 2002, Looking for Blackfellas' Point: An Australian History of Place, UNSW Press, Sydney.

McNiven, Ian 1989, 'Aboriginal shell middens at the mouth of the Maroochy River, southeast Queensland', Queensland Archaeological Research 6: 28-52.

Melton, Chas 1919, 'When Woolloongabba was wattle-scented', Historical Society of Queensland Journal 1(6): 347.

Memmott, Paul 1996, 'From the Curry to the Weal: Aboriginal town camps and compounds of the western back-blocks', Fabrications: The Journal of the Society of Architectural Historians, Australia and New Zealand 7(1): 1-50. doi.org/10.1080/10331867.1996.1 0525096.

Memmott, Paul 2002, 'Sociospatial structures of Australian Aboriginal settlements', Australian Aboriginal Studies 1: 66-87.

Memmott, Paul 2007, Gunyah, Goondie and Wurley: The Aboriginal Architecture of Australia, University of Queensland Press, St Lucia.

Merlan, Francesca 1998, Caging the Rainbow: Places, Politics, and Aborigines in a North Australian Town, University of Hawai'i Press, Honolulu.

Merlan, Francesca 2005, 'Explorations towards intercultural accounts of socio-cultural reproduction and change', Oceania 75(3): 167-82. doi.org/10.1002/j.1834-4461.2005. tb02878.x.

Merlan, Francesca 2006, 'European settlement and the making and unmaking of Aboriginal identities', Australian Journal of Anthropology 17(2): 179-95. doi. org/10.1111/j.1835-9310.2006.tb00056.x.

Mitchell Aboriginal Community and Mitchell State School 1985, Nalingu-Memories of the Mitchell Yumba, Mitchell Community Aboriginal History and Culture Project Working Group, Mitchell, Queensland.

Moretti, Marco 2012, International Law and Nomadic People, AuthorHouse, Milton Keynes.

Morgan, George 2006, Unsettled Places: Aboriginal People and Urbanisation in New South Wales, Wakefield Press, Adelaide. 
Munro, Colin 1862, Fern Vale, or, the Queensland Squatter, 3 vols, T.C. Newey, London.

'Musgrave Park, South Brisbane: Conservation Management Study' 2001, www.streetwalkers guidetowestend.com/uploads/1/3/2/0/13201772/conservation_study_-_musgrave _park_pt_1_no_81.pdf, accessed 28 May 2018.

Nunn, Elizabeth, Mavis Baxter and Nundah and Districts Historical Society 1998, Historical Appraisal: Kalinga Greenspace Nundah, Nundah and Districts Historical Society, Nundah.

Parke, John 2012, The Rich History of the Fishers of Moreton Bay, Moreton Bay Seafood Industry Association, Cleveland, Queensland.

Petrie, Constance 1904, Tom Petrie's Reminiscences of Early Queensland, Lloyd O'Neill, Hawthorn, UK.

Pope, May 1988, 'Aboriginal adaptation to early colonial labour markets: The South Australian experience', Labour History 54: 1-15. doi.org/10.2307/27504432.

Rapoport, Amos 1972, 'Australian Aborigines and the definition of place', in Environmental Design; Research and Practice - Proceedings of the EDRA 3/AR B Conference, W.J. Fitchell (ed.), University of California Press, Los Angeles: 3.3.1-3.3.14.

Reece, Robert 1974, Aborigines and Colonists in New South Wales in the 1830s and 1840s, Sydney University Press, Sydney.

Reynolds, Henry 1974, 'Racial violence in North Queensland', Lectures on North Queensland History: Second Series, B.J. Dalton (ed.), History Department, James Cook University, Townsville, Queensland.

Reynolds, Henry 1978, 'Fringe camps in nineteenth century Queensland', Lectures on North Queensland History: Third series, B.J. Dalton (ed.), History Department, James Cook University, Townsville, Queensland.

Reynolds, Henry 1990, With the White People, Penguin, Ringwood, Victoria.

Reynolds, Henry 2013, Forgotten War, NewSouth Publishing, Sydney.

Richens, P.G. 1978, 'Drinking water for Redcliffe', Boama 1: 2.

Robinson, Sue 2002, 'Keep them away from Brisbane: Bribie Island Aboriginal reserves 1877-79 and 1891-92', Moreton Bay Matters, Murray Johnson (ed.), Brisbane History Group, Brisbane.

Romano, Diana 2008, “'We is Human Beings Musgrave People”: Connecting to Urbanised Place and Country in Musgrave Park, South Brisbane', BA (Hons) thesis, School of Social Science, University of Queensland.

Ross Planning 2010, Queens Park Land Management Plan, Ipswich City Council, Ipswich, Queensland. 
Rowland, Mike and Malcolm Connolly 2002, 'Towards GIS mapping and spatial modelling of archaeological sites in the southeast Queensland bioregion', Queensland Archaeological Research 13: 9-62. doi.org/10.25120/qar.13.2002.67.

Russell, Lynette 2015, 'Tickpen, Boro Boro: Aboriginal economic engagements in early Melbourne', in Settler Colonial Governance in Nineteenth Century Victoria, Leigh Boucher and Lynette Russell (eds), ANU Press and Aboriginal History Inc., Canberra: 27-46.

Scott, Joanne and Ross Laurie 2008, Showtime: A History of the Brisbane Exhibition, University of Queensland Press, St Lucia.

Smith, Anita and Wendy Beck 2003, 'The archaeology of no man's land: Aboriginal camps at Corindi Beach, mid-north NSW coast', Archaeology in Oceania 38(2): 66-78. doi.org/ 10.1002/j.1834-4453.2003.tb00530.x.

Smith, Pam A. 2001, 'Station camps: Identifying the archaeological evidence for continuity and change in post-contact Aboriginal sites in the south Kimberley, Western Australia', Australian Archaeology 53: 23-31. doi.org/10.1080/03122417.2001.11681718.

Steele, John G. 1972, The Explorers of Moreton Bay 1770-1830, University of Queensland Press, St Lucia.

Steele, John G. 1975, Brisbane Town in Convict Days 1824-1842, University of Queensland Press, St Lucia.

Steele, John G. 1983, Aboriginal Pathways, Southeast Queensland and the Richmond River, University of Queensland Press, St Lucia.

Strong, Michael and Archaeo 2003, 'Cultural Heritage Survey and Assessment of Musgrave Park South Brisbane’, Report for Jagera Daran, Stafford.

Thorpe, Bill 2002, 'Remembering reserves: the Deebing Creek Aboriginal Mission and Cemetery in Aboriginal history and memory', Queensland Review 9(2): 95-114. doi.org/10.1017/S1321816600002993.

Turnstone Archaeology and Jagera Daran 2011, 'Rebuilding the Campfires: Aboriginal Cultural Heritage Investigation of Queen's Park, Ipswich', report by Turnstone Archaeology, Sandstone Point, Queensland.

Ulm, Sean, Bryce Barker, Andrew Border, Jay Hall, Ian Lilley, Ian McNiven, Robert Neal and Mike Rowland 1995, 'Pre-European coastal settlement and use of the sea: A view from Queensland', Australian Archaeology 41: 24-26. doi.org/10.1080/03122417.1995 .11681555 .

Walters, Ian 1985, 'The Toorbul Point Aboriginal fish trap', Queensland Archaeological Research 2: 38-49.

Wharton, Herb 1999, Yumba Days, University of Queensland Press, St Lucia.

Wynnum North State Primary School Centenary Committee 1982, 1882-1982 - A Century of Progress, Wynnum North State Primary School and William Brooks and Co., Brisbane. 
This text is taken from Aboriginal History, Volume 42, 2018, edited by Ingereth Macfarlane, published 2018 by ANU Press, The Australian National University, Canberra, Australia.

doi.org/10.22459/AH.42.2018.07 